\title{
Detection of Avibacterium paragallinarum in Poultry Carcass
}

\author{
Sandeep Dwivedi $^{1 *}$, Madhu Swamy ${ }^{1}$ and Ajit Pratap Singh ${ }^{2}$ \\ ${ }^{1}$ Department of Veterinary Pathology, College of Veterinary Science and A.H., Nanaji \\ Deshmukh Veterinary Science University, Jabalpur (M.P.) 482001 \\ ${ }^{2}$ Animal Biotechnology Center, Nanaji Deshmukh Veterinary Science University, Jabalpur \\ (M.P.) 482001, India \\ *Corresponding author
}

\section{A B S T R A C T}

\begin{tabular}{|l|}
\hline Ke y w o r d s \\
Infectious coryza, \\
Polymerase chain \\
reaction, Poultry
\end{tabular}

The present study was carried out for the detection of Avibacterium paragallinarum from Avian Infectious Coryza suspected poultry carcasses of Jabalpur region. The polymerase chain reaction (PCR) was standardized for the diagnosis of Infectious Coryza by using live Avibacterium paragallinarum broth containing Modesto, Spross and 0083 strains received from Stallen South Asia Private Limited, Mumbai, as source of DNA of $A$. paragallinarum. Poultry carcasses $(n=60)$ showing characteristic gross lesions of Avian Infectious Coryza were investigated in the present study. Samples were collected from the infra orbital sinus, nasal cavity and trachea of the entire sixty carcass. The swabs of the three different sites from one bird were mixed and then pooled sixty samples were tested by PCR using oligo primer specific to $16 \mathrm{~S}$ rRNA of Avibacterium paragallinarum. PCR analysis revealed 08 positives (13.33\%) for Avian Infectious coryza out of total 60 samples tested. It is concluded that PCR an early, rapid, accurate and highly sensitive diagnostic technique with the ability to substitute conventional cultural examination can be used to prevent the economic losses associated with the disease.

\section{Introduction}

Infectious Coryza is a cosmopolitan disease and had been reported from almost all the countries around the world involved in poultry production including India. Respiratory affections of poultry can be initiated by various pathogens, including a variety of viruses, bacteria, and fungi. Environmental fluctuations may augment the pathogens to produce the clinically observed signs and lesions. Infectious coryza is a respiratory disease of chickens caused by the bacterium,
Avibacterium paragallinarum and it primarily affects upper respiratory tract, including the involvement of nasal passages, infra orbital and paranasal sinuses.

Even though the disease is not associated with heavy mortality losses it possesses significant financial liability to chicken farmers Ali et al., (2013). The disease take a toll on the farmers pocket associated in the terms of poor growth performance in growing birds including broilers, markedly reduced (10-40\%) egg production in layers and increased culling 
rates in meat chickens. Endemicity of the disease is maintained by chronically infected birds or recovered healthy birds as they act as reservoirs of infection in a population (Muahhamad and Sreedevi, 2015).

Economic losses associated with this disease needs to be lowered down so an early, rapid and accurate diagnosis is required. In most of the developing countries including India, conventional diagnosis of Infectious Coryza is based on clinical signs, demonstration of satellite colonies by cultural examination and confirming them by biochemical tests.

However, factors like simultaneous occurrence of combined respiratory infections, occurrence of NAD independent strains, overgrowth of fast growing bacteria, which mask the growth of $A$. paragallinarum, requirement of special media for culturing, presence of different biovars, etc. make the confirmatory diagnosis of the disease difficult. Hence, nucleic acid based techniques are considered as the best alternative tools for easy and rapid confirmatory diagnosis (Anjaneya et al., 2014).

The present study was taken up to detect $A$. paragallinarum by Polymerase chain reaction from Avian Infectious Coryza suspected poultry carcasses received from 20 different organized poultry farms..

\section{Materials and Methods}

Study period covered the rainy and winter months with high relative humidity and temperature ranging from $6^{0} \mathrm{C}$ to $38^{0} \mathrm{C}$. All the birds received from twenty various poultry farms comprising broiler and layer flocks were grossly evaluated for presence of Coryza. Samples for molecular diagnosis were collected from the birds $(n=60)$ with lesions strongly suggestive of Avian Infectious Coryza(IC).

\section{Collection of samples}

Sixty pooled ocular, infraorbital sinus, nasal and tracheal swabs were collected (Fig. 1) in PBS and stored at $4^{\circ} \mathrm{C}$ till used for confirmation by direct PCR performed as per the protocol reported by earlier workers (Chen et al., 1996).

\section{Reference strains}

The standard reference strains of Avibacterium paragallinarum (Spross, Modesto and 0083) were procured from Stallen South Asia Private Limited, Mumbai, Maharashtra, to standardize of polymerase chain reaction (PCR) protocol and as positive control in PCR test for field samples.

\section{DNA extraction}

The swabs collected from the birds were soaked in $1.5 \mathrm{ml}$ of phosphate-buffered saline in $2 \mathrm{ml}$ micro centrifuge Eppendorf tube and centrifuged at $2000 \mathrm{rpm}$ for $3 \mathrm{~min}$ to settle the debris. The supernatant was then transferred to a new $2 \mathrm{ml}$ Eppendorf tube and again centrifuged at $13,000 \mathrm{rpm}$ for $15 \mathrm{~min}$. The supernatant was discarded and the pellet was stored at $-20^{\circ} \mathrm{C}$ until use. The pellet was suspended in $20 \mu \mathrm{l}$ of $1 \mathrm{x}$ DNA lysis buffer (8.8 $\mu$ l Distilled water, $1 \mu$ l Proteinase-K, 10 $\mu 1$ Tris-Base $1 \mathrm{M} \mathrm{pH}(8.3) \mathrm{NP}-40 \quad 0.5 \mu \mathrm{l}$ and Tween-20 $0.5 \mu \mathrm{l}$ ) and incubated at $56^{\circ} \mathrm{C}$ for 1 hour. The samples were then heated at $98^{\circ} \mathrm{C}$ for $10 \mathrm{~min}$ to inactivate the proteinase- $\mathrm{K}$ and then held on ice for $10 \mathrm{~min}$ before being used in the PCR.

\section{Assessment of concentration of extracted DNA}

The concentration of the extracted DNA was assessed with the aid of spectrophotometry. $1 \mu \mathrm{l}$ of extracted DNA was used and absorbency at $260 \mathrm{~nm}$ and $280 \mathrm{~nm}$ was 
recorded using NanoDrop 2000 (ThermoFischer scientific) and ratio of the absorbance at 260 and $280 \mathrm{~nm}$ was calculated. The samples giving a ratio of 1.7 to 1.9 were considered as pure DNA and used for further steps of the study.

\section{Polymerase chain reaction}

The published oligo primers (Table 1) specific to $16 \mathrm{~S}$ rRNA of Avibacterium paragallinarum were synthesized at Integrated DNA Technology (IDT) Inc. and utilized in present study. Freeze dried oligo primers were reconstituted in nucleus free water to the volume equivalent to the mass of primer (Mass $/ \mu \mathrm{g}$ ) and further diluted in nucleus free water to give a final concentration of 10 $\mathrm{pmol} / \mu \mathrm{l}$ (Chen et al., 1996).

Dream Taq green dye PCR Master Mix (Thermo Fischer scientific) was used for PCR reaction. About $25 \mu \mathrm{l}$ of reactions were used and the protocol was initially standardized for optimizing the concentration of components of the reaction mixture in the PCR assay and then by varying the annealing temperature and cycling conditions using Verity veriflex 96 well thermo cycler (Thermo Fischer scientific). The PCR product was stored at $20^{\circ} \mathrm{C}$ until use. The standardized protocol was further used in PCR for field samples collected. The reaction volume used was $25 \mu 1$ in which Dream Taq green dye PCR Master mix $1 \mu 1$ of target DNA, $1 \mu$ each of forward and reverse primers and $9.5 \mu 1$ of Nucleus free water were used and the PCR was carried out as per standardized cycling conditions (Table 2). Negative control as distilled water was used to cross check any contamination of foreign DNA in reaction component. PCR amplification was confirmed by running $10 \mu 1$ of PCR product from each tube on $1.5 \%$ agarose gel at a constant voltage, $70-80 \mathrm{~V}$ for 60 minute in $0.5 \mathrm{X}$ TAE buffer. Ethidium bromide was incorporated in $100 \mathrm{ml}$ of agarose gel at the rate of $5 \mu \mathrm{l}$ of $1 \%$ solution. The amplified product was visualized as a single compact fluorescent band of expected size under U-V light and documented by gel documentation system (Syngene, Gene genius bio imaging).

\section{Results and Discussion}

During the present study, 60 dead birds highly suspected for Infectious Coryza from Jabalpur region were investigated. The birds were received from 20 farms in and around Jabalpur. Apart from the postmortem examination efforts were made to visit farms from which the birds were received, for collection of history and examining the birds with clinical signs.

The birds were showing signs of acute upper respiratory tract infections like open mouth breathing (Fig. 2), coughing, sneezing, conjunctivitis, oulonasal discharge, facial oedema unilateral to bilateral oedema of wattle (Fig. 3) and comb. Post mortem examination of the birds revealed the involvement of nasal passages and sinus (Fig. 4) with serous to mucoid nasal discharge, facial edema and conjunctivitis and inflammation of the upper respiratory tract in almost all the cases. During the post-mortem examination, there was no characteristic feature of any other respiratory viral pathogen.

\section{DNA extraction}

The presence of DNA extracted from live bacterial broth was confirmed by agarose gel electrophoresis followed by ethidium bromide staining. When viewed under UV transilluminator, presented a single band of DNA in the gel, just below the well in all the samples. The ratio of the absorbance at 260 and 280 was found to be 1.8 or more for all the samples from live Avibacterium paragallinarum (A) broth. 


\section{Standardization of PCR}

PCR was carried out as described under materials and methods. The size of the amplified product was analyzed by agarose gel electrophoresis using 100bp standard DNA molecular size marker. The size of the amplified product was found to be $500 \mathrm{bp}$ (Fig. 5), which was the size of the amplicon defined by selected primers. Negative control showed no amplification indicating that the amplified PCR product was specific to bacteria Avibacterium paragallinarum.
Screening samples suspected for infectious coryza by applying PCR

The standardized protocol was used to screen the field samples. The results of PCR analysis showed 08 positives (13.33\%) for AP out of total 60 samples tested. All the positive samples were collected during the winter months. Amongst the 08 sample tested positive for AP, 07 were from layer birds and only one was from broiler.

Table.1 Detail of primer used for PCR

\begin{tabular}{|c|c|c|}
\hline Primer & Sequence & Size \\
\hline N1 & 5' TGA GGG TAG TCT TGC ACG CGA AT 3' & 500bp \\
\hline $\boldsymbol{R 1}$ & 5'CAA GGT ATC GAT CGT CTC TCT ACT 3' & \\
\hline
\end{tabular}

Table.2 Reaction programme for PCR

\begin{tabular}{|c|c|c|}
\hline \multicolumn{2}{|l|}{ Steps } & Temperature and time \\
\hline \multicolumn{2}{|c|}{ Initial denaturation } & $94^{\circ} \mathrm{C}$ for 5 minutes \\
\hline Denaturation & & $94^{\circ} \mathrm{C}$ for 1 minute \\
\hline Annealing & 35 cycles & $62^{\circ} \mathrm{C}$ for 1 minute \\
\hline Extension & & $72^{\circ} \mathrm{C}$ for 1 minute \\
\hline \multicolumn{2}{|l|}{ Final extension } & $72^{\circ} \mathrm{C}$ for 10 minutes \\
\hline
\end{tabular}

Fig.1 Collection of swab from conjunctival sac of affected layer bird

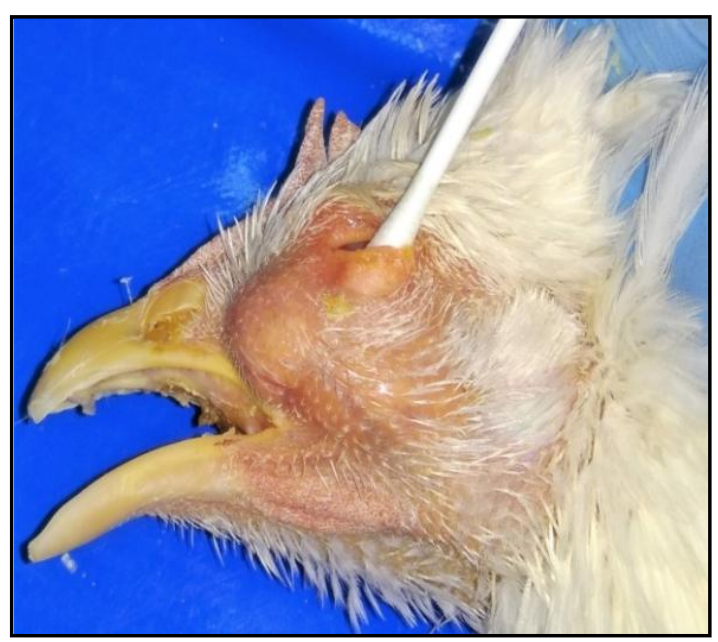


Fig.2 Layer grower showing severe conjunctivitis and open mouth breathing

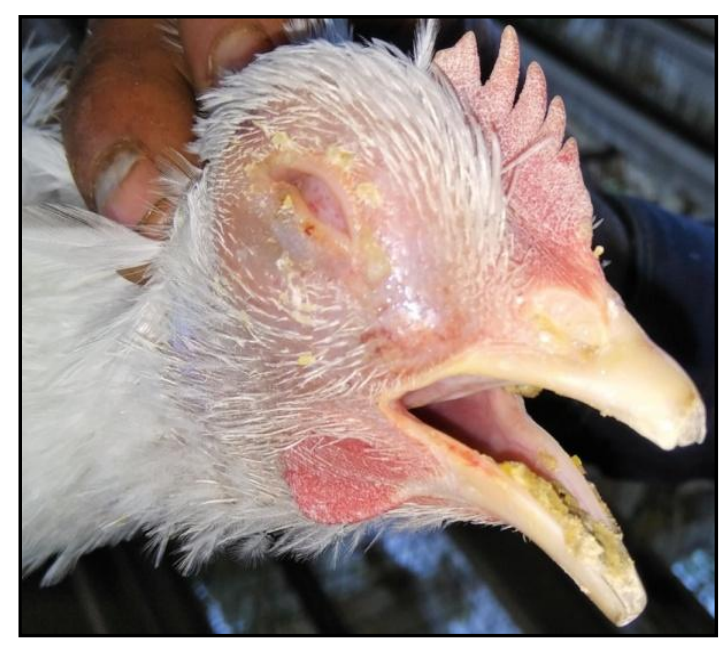

Fig.3 Bird with unilateral swelling of wattle

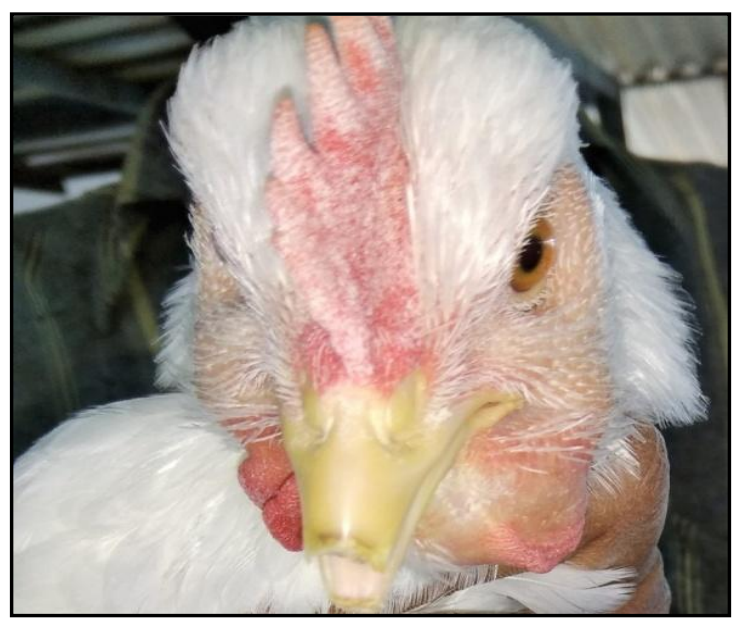

Fig.4 Bird affected with IC having caseous material in infra orbital sinus

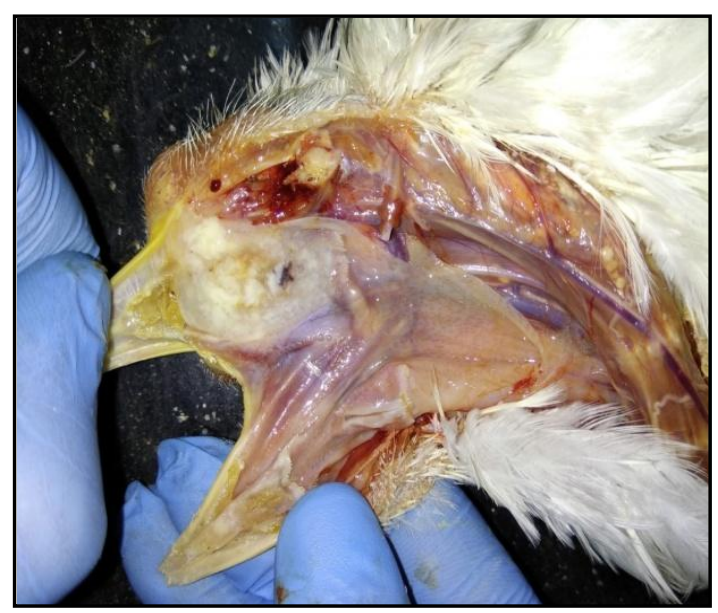


Fig.5 500bp PCR amplified product of Avibacterium paragallinarum from infectious Coryza suspected sample. M: 100bp ladder, L3, L7 and L8: positive samples, L9: negative control, L10: positive control.

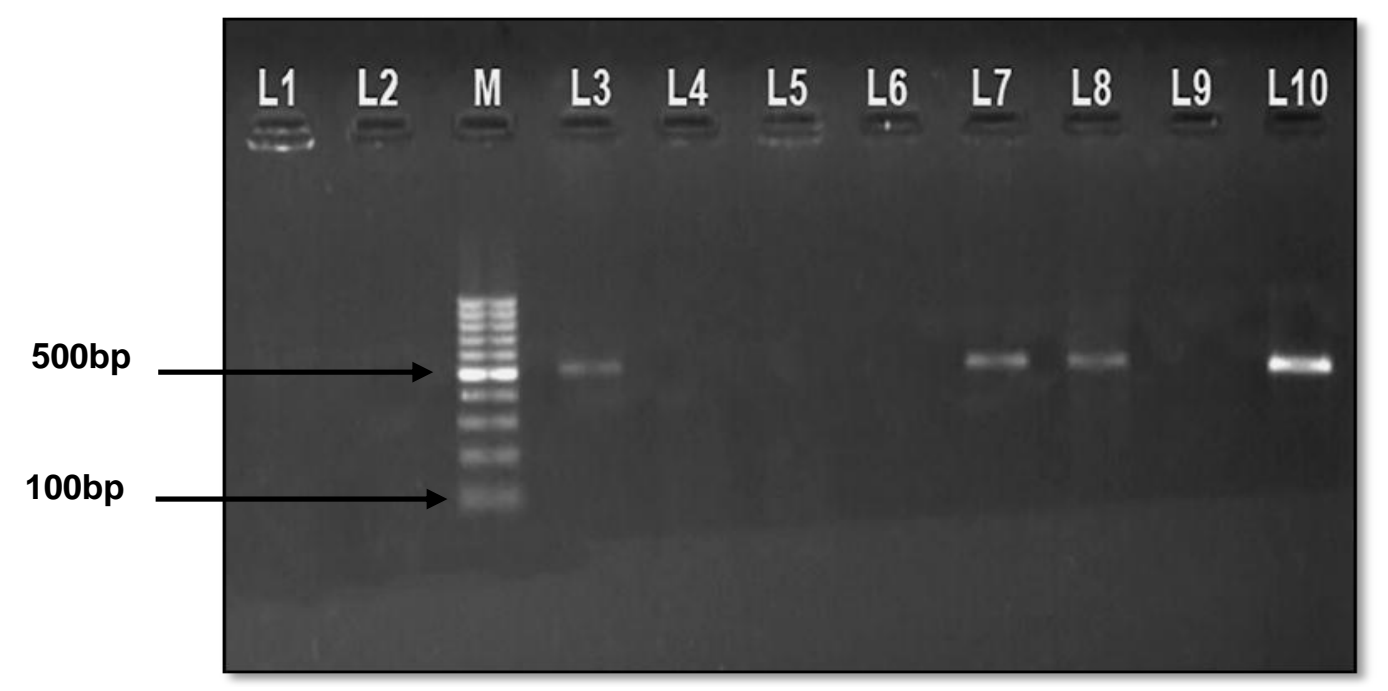

Infectious coryza puts considerable economic impact, particularly in multi aged farms. The isolation and identification of the causative agent, of $A$. paragallinarum is difficult and demanding. The conventional diagnosis of infectious coryza is based on the appearance of typical clinical signs, isolation of satellite organisms and further biochemical characterization. A. paragallinarum depends on $\mathrm{V}$ factor or NAD for its growth. $A$. paragallinarum is a slow growing organism which may take $36-48 \mathrm{~h}$ or even more time to show detectable colonies. Moreover vigorous growth of the other bacteria, which are in coinfection will mask the growth of the $A$. paragallinarum and the satellitic growth may not be appreciated (Sandoval et al., 1994 and Brag et al., 1997). Avibacterium avium and Avibacterium volatinum considerd as the normal flora of chicken produce similar satellitic colony as $A$. paragallinarum on blood agar. Reports about emergence of NAD-independent $A$. paragallinarum, which will not show satellitic growth, are again complicating the conventional method of identification $^{5}$.
A. paragallinarum have strict nutritional demands when grown in-vitro, NAD, oleic albumin complex, chicken serum and thiamine must be used to obtain pure cultures which raise the cost of isolation (Badouei et al., 2014). Media like (TM/SN) described previously had been useful for characterization tests following isolation but are not suitable for isolation, Rimler (1979). These difficulties associated with conventional culture method and biochemical characterization of infectious coryza made the molecular technique, PCR an attractive alternative. Since no standard culture of $A$. paragallinarum was available and DNA of $A$. paragallinarum was isolated from live Avibacterium paragallinarum broth received from Stallen South Asia Private Limited, Mumbai which contained page reference strains; Modesto, Spross and 0083. Published primers were used in the present study which was successfully used by many other workers worldwide (Kaur et al., 2004). A 35 cycle PCR reaction with annealing temperature of $62^{\circ} \mathrm{C}$ for 1 min was found optimum for amplification of $500 \mathrm{bp}$ products.

Eight out of $60(13.33 \%)$ samples were 
positive for Avian Infectious coryza this may be due to the reason that the birds were at chronic stage of disease and may have gone antibiotic treatment before death. Samples from the acute stage of the disease for accurate diagnosis of infectious coryza were recommended by previous workers ${ }^{8}$. Antibiotic treatment significantly reduces the capacity of both conventional cultural examination and PCR test to detect $A$. paragallinarum (Chen et al., 1998). Moreover maximum number of positive samples was from layer farms. Infectious Coryza was reported as the most prevalent disease in layers with an overall prevalence of 33.75 by earlier workers (Ahmad et al., and Sultana et al., 2012). The workers have opined that incidence of infection with $\mathrm{AG}$ is more in older age groups and that could be the reason of increased prevalence of AG found in layers in our study also.

To conclude, for preventing the economic losses associated with the disease, an early, accurate and rapid diagnosis is essential. PCR is a rapid and highly sensitive diagnostic technique which can substitute conventional cultural examination. Failure to detect the positive samples by PCR, even when the lesions are strongly indicative of Avibacterium paragallinarum infection can be due to low antigen concentration in the samples. Pooling of samples from two to three birds instead of examining samples from individual birds and collecting the samples from the birds in acute phase of the disease can significantly reduce the false negatives.

\section{References}

Ali, M., Hossain, M.S., Akter, S., Khan, M.A.H.N.A. and Hossain, M.M. (2013). Pathogenesis of Infectious Coryza in chickens (Gallus gallus) by Avibacterium paragallinarum in isolates of Bangladesh. The
Agriculturists, 11(1): 39-46.

Muhammad, T. N., and Sreedevi, B. (2015). Detection of Avibacterium paragallinarum by Polymerase chain reaction from outbreaks of Infectious coryza of poultry in Andhra Pradesh. Veterinary world, 8(1), 103.

Anjaneya, S.D.S., Dhama, K., Wani, M.Y. and Gowthaman, V. (2014). Molecular characterization of Avibacterium paragallinarum isolated from poultry flocks of India. Asian Journal of Animal and Veterinary Advances, 9(7): 440451.

Chen, X., Miflin, J. K., Zhang, P. and Blackall, P. J. (1996). Development and application of DNA probes and PCR tests for Haemophilus paragallinarum. Avian Disease, 40: 398-407.

Sandoval, V. E., Terzolo, H. R., and Blackall, P. J. (1994). Complicated infectious coryza outbreaks in Argentina. Avian diseases, 672-678.

Bragg, R. R., Greyling, J. M., and Verschoor, J. A. (1997). Isolation and identification of NAD- independent bacteria from chickens with symptoms of infectious coryza. Avian Pathology, 26(3), 595606.

Badouei, M. A., Sadrzadeh, A., Azad, N., Blackall, P., Madadgar, O., and Charkhkar, S. (2014). Isolation and molecular identification of Avibacterium paragallinarum in suspected cases of infectious coryza. Turkish Journal of Veterinary and Animal Sciences, 38(1), 46-49.

Rimler, R. B. (1979). Studies of the pathogenic avian haemophili. Avian diseases, 1006-1018.

Kaur, J., Sharma, N.S., Gupta, K. and Singh, A. (2004). Epidemiological studies of infectious coryza in chickens in northern India. Indian Journal of Animal Science, 74(5): 462-465.

Chen, X., Song, C., Gong, Y. and Blackall, P. 
J. (1998). Further studies on the use of a polymerase chain reaction test for the diagnosis of infectious coryza. Avian Pathology, 27(6), 618-624.

Ahmad, I., Anjum, M. S. and Hanif, M. (2012). Prevalence of poultry diseases at high altitudes of district Poonch azad Jammu and Kashmir. Pakistan Journal of Science, 64: (4).

Sultana, R., Siddique, B., Ali, R., Chaudhary, S.I. and Maqbool, A. (2012). A study on the prevalence of respiratory diseases in broiler and layer flocks in and around Lahore district. Punjab University Journal of Zoology, 27(1): 13-17.

\section{How to cite this article:}

Sandeep Dwivedi, Madhu Swamy and Ajit Pratap Singh. 2018. Detection of Avibacterium paragallinarum in Poultry Carcass. Int.J.Curr.Microbiol.App.Sci. 7(12): 1547-1554. doi: https://doi.org/10.20546/ijcmas.2018.712.182 